\title{
PENGARUH KUALITAS PELAYANAN PETUGAS TERHADAP KEPUASAN PENGUNJUNG DI OBJEK WISATA SEJARAH BENTENG MARLBOROUGH DI KOTA BENGKULU
}

\author{
Handika Fikri Pratama \\ Alumni Prodi Usaha Perjalanan Wisata \\ FISIP Universitas Riau \\ Email: deeka39@gmail.com
}

\begin{abstract}
ABSTRAK
Handika Fikri Pratama; Penelitian ini bertujuan untuk mengetahui pengaruh kualitas pelayanan (Reliability, Responsiveness, Assurance, Empathy, dan Tangibles) baik secara parsial maupun simultan terhadap kepuasan pelanggan dan untuk mengetahui pengaruh yang lebih dominan dari kualitas pelayanan. Penelitian ini menggunakan metode kuantitatif. Ada 100 sampel yang dikumpulkan menggunakan accidental sampling. Dikumpulkan dengan menggunakan kuesioner dan dokumentasi. Uji instrumen dilakukan dengan uji validitas dan reliabilitas. Regresi linier berganda dan uji asumsi klasik yang digunakan sebagai analisis uji. Uji hipotesis dilakukan dengan uji $\mathrm{F}$ dan uji t.

Hasil penelitian ini menunjukkan mengambil nilai-nilai variabel Reliability, Responsiveness, Assurance, Empathy dan variabel Tangibles berpengaruh signifikan terhadap variabel dependen (Y) secara bersamaan. Tangibles tidak memiliki pengaruh yang signifikan terhadap variabel (Y) sebagian. variabel Reliability, Responsiveness, Assurance dan Empathy variabel berpengaruh signifikan terhadap variabel dependen (Y). Nilai koefisien determinasi ( $R$ Square) 97,6\% itu berarti bahwa variabel independen dapat menjelaskan variabel dependen, sedangkan $2,4 \%$ sisanya dijelaskan oleh variabel independen lainnya yang tidak termasuk dalam penelitian ini.
\end{abstract}

\begin{abstract}
Handika Fikri Pratama; This research is intended to know the influence of service quality (Reliability, Responsiveness, Assurance, Empathy and Tangibles) either partially or simultaneously to the satisfaction of customers and to know the more dominant influence from quality service. This research used quantitative method. There were 100 samples collected using accidental sampling. Collected using questioner and documentation. Instrument test is done by validity and reliability test. Multiple linear regression and classical assumption test used as analysis test. Hypothesis test is done by $F$ test and $t$ test.

Result of this research shows take value of value Reliability, Responsiveness, Assurance, Empathy and Tangibles variable have significant influence to dependent variable (Y) simultaneously. Tangibles don't have significant influence to variable (Y) Partially. Reliability, Responsiveness, Assurance and Empathy variable have significant influence to dependent variable $(Y)$. The value of determination coefficient ( $R$ Square) $97,6 \%$ it means that the independent variable may describe the dependent variables, while the remaining $2,4 \%$ is explained by the other independent variables which are not included in the this research.
\end{abstract}

Keywords : Service Quality, Customer's Satisfactions.

\section{LATAR BELAKANG}

Pariwisata merupakan industri perdagangan jasa yang memiliki mekanisme pengaturan yang kompleks karena mencakup pengaturan pergerakan wisatawan dari negara asalnya, di daerah tujuan wisata hingga kembali ke negara asalnya yang melibatkan berbagai hal seperti transportasi, penginapan, restoran, pemandu wisata, dan lain-lain. Oleh karena itu, industri 
pariwisata memegang peranan yang sangat penting dalam mengembangkan pariwisata. Dalam menjalankan perannya, industri pariwisata harus menerapkan konsep dan peraturan serta panduan yang berlaku dalam pengembangan pariwisata agar mampu mempertahankan dan meningkatkan jumlah kunjungan wisatawan yang nantinya bermuara pada pemberian manfaat ekonomi bagi industri pariwisata dan masyarakat lokal.

Karena persaingan di bidang usaha terutama di bidang jasa yang semakin ketat, diikuti dengan kemajuan ilmu pengetahuan dan teknologi yang semakin pesat membawa pengaruh lingkungan yang cukup besar sehingga menyebabkan setiap perusahaan harus menempatkan orientasi kepada kepuasan konsumen sebagai tujuan utama. Keadaan ini tampak dari banyaknya perusahaan yang menyertakan komitmennya terhadap kepuasan konsumen dalam pernyataan misi, tujuan dan iklan. Selain itu, banyaknya perusahaan yang menyadari bahwa kepuasan konsumen merupakan suatu tuntutan dari komitmen sehingga perusahaan harus memberikan atau mewujudkan dengan berbagai macam strategi agar dapat mempertahankan konsumennya.

Sejalan dengan pertumbuhan ekonomi yang modern maka pemerintah daerah dituntut untuk mengelola objek wisatanya lebih professional dan efisien dalam menghadapi persaingan. Dengan adanya persaingan dunia usaha wisata yang semakin tajam menuntut pula pemerintah daerah untuk peka dan cermat didalam memilih dan mengembangkan objek wisata yang sesuai dengan minat para konsumen lokal dan mancanegara. Letak objek wisata yang strategis dan dekat dengan kota seperti halnya dengan Benteng Marlborough akan lebih menguntungkan karena sebagian konsumen akan lebih menyukai lokasi objek wisata yang bagus dan dapat dijangkau dengan mudah. Lokasi wisata yang berada dalam kota yang didukung dengan tranportasi yang lancar dan pelayanan yang baik secara tidak langsung akan mempengaruhi minat konsumen untuk mengunjungi objek wisata tersebut.

Selain masalah lokasi objek wisata, masih ada masalah lain yang tidak kalah penting yaitu masalah pelayanan. Para pengelola objek wisata/perusahaan harus dapat memberikan palayanan yang memuaskan pada konsumen agar merasa tertarik dan senang untuk berkungjung ke objek wisata tersebut. Pelayanan yang cepat dan penampilan yang ramah sangat memungkinkan konsumen akan tertarik untuk kembali dan menginformasikannya kepada orang lain.

Menurut Radiosunu (2001) "kualitas pelayanan merupakan bentuk penilaian konsumen terhadap tingkat pelayanan yang diterima (perceived service) dengan tingkat pelayanan yang diharapkan (Expected service)". Tuntutan pelanggan dalam hal pelayanan yang diterima, menyebabkan pihak pengelola bertindak semaksimal mungkin untuk memberikan pelayanan yang terbaik bagi konsumen. Kualitas pelayanan (service quality) pada sebuah objek wisata dapat diketahui dengan cara mengerti persepsi para pelanggan atas pelayanan yang mereka terima yang berasal dari para pengelola atau pemandu objek wisata tersebut. Pengembangan dan pembangunan fasilitas pendukung objek wisata Benteng Marborough agar dapat bersaing dalam era globalisasi ini sangatlah dibutuhkan, karena apabila pembangunan fasilitas pendukung dan pelayanan terhadap para wisatawan tidak dilakukan maka tidak mustahil objek wisata sejarah Benteng Marborough lama kelamaan akan mengalami kemunduran dan bahkan tidak diminati lagi oleh para wisatawan sehingga menjadi bangunan kuno yang menjadi tinggal kenangan dalam dalam sejarah nasional Indonesia khususnya bagi Sejarah bagi masyarakat Kota Bengkulu.

Selain infrastruktur yang masih sangat kurang untuk menuju objek wisata ke Benteng Marlborough, permasalahan lainnya adalah promosi yang masih kurang dan pelaksanaan even wisata tidak tetap setiap tahunnya. Kondisi ini dapat dilihat dari jumlah kunjungan wisatawan yang mengalami fluktuasi kunjungan wisata setiap tahunnya, adapun data jumlah kunjungan wisatawan ke Benteng Marlborough setiap tahunnya dapat dilihat pada tabel berikut ini: 
Tabel 1. Jumlah Pengunjung Objek Wisata Benteng Marlborough Tahun 2008-2012 (Orang)

\begin{tabular}{|c|c|c|c|}
\hline Tahun & Jumlah Pengunjung & Target & Persentase (\%) \\
\hline 2008 & 95.575 & 100.000 & 95,58 \\
\hline 2009 & 97.986 & 100.000 & 97,99 \\
\hline 2010 & 110.825 & 125.000 & 88,05 \\
\hline 2011 & 115.765 & 130.000 & 89.05 \\
\hline 2012 & 109.503 & 130.000 & 84,23 \\
\hline
\end{tabular}

Sumber : Laporan Tahunan Dinas Kebudayaan dan Pariwisata Provinsi Bengkulu, 2013

Berdasarkan tabel 1, dapat diketahui bahwa jumlah kunjungan di objek wisata Benteng Marlborough setiap tahunnya mengalami peningkatan (tetapi belum mencapai target yang diinginkan) kecuali pada tahun 2012 mengalami penurunan dari 115.765 wisatawan menjadi 109.503 wisatawan atau mengalami penurunan sebesar 1,18 persen. Pertanyaan yang timbul disini adalah apakah dengan tingkat kunjungan wisata yang cenderung meningkat setiap tahun tersebut pelayanan yang diberikan sudah memenuhi harapan konsumen.

\section{TINJAUAN TEORI}

Zeithaml, Berry dan Parasuraman, (dalam Zulian Yamit, 2005:11-12) telah melakukan berbagai penelitian terhadap beberapa jenis jasa, dan berhasil mengidentifikasi lima dimensi karakteristik yang digunakan oleh para konsumen (pengunjung) dalam mengevaluasi kualitas pelayanan. Kelima dimensi karakteristik kualitas pelayanan tersebut adalah :

- Reliability (keandalan), yaitu kemampuan dalam memberikan pelayanan dengan segera dan memuaskan serta sesuai dengan yang telah dijanjikan.

- Responsiveness (daya tanggap), yaitu keinginan para staf untuk membantu para konsumen (pengunjung) dan memberikan pelayanan dengan tanggap.

- Assurance (jaminan), yaitu mencakup kemampuan, kesopanan dan sifat dapat dipercaya yang dimiliki para staf, bebas dari bahaya, resiko ataupun keragu-raguan.

- Emphaty (empati), yaitu meliputi kemudahan dalam melakukan hubungan, komunikasi yang baik, dan perhatian dengan tulus terhadap kebutuhan konsumen (pengunjung).

- $\quad$ Tangibles (bukti langsung), yaitu meliputi fasilitas fisik, perlengkapan, karyawan, dan sarana komunikasi.

Dimensi kualitas yang dikemukakan oleh Zeithaml, Berry dan Parasuraman tersebut berpengaruh pada harapan pengunjung dan kenyataan yang mereka terima. Jika kenyataannya pengunjung menerima pelayanannya berkualitas dan jika kenyataannya pengunjung menerima pelayanan kurang atau sama dari harapannya, maka pengunjung akan mengatakan pelayanannya tidak berkualitas atau tidak memuaskan.

Dimensi kualitas di atas dapat dijadikan dasar bagi pelaku bisnis untuk mengetahui apakah ada kesenjangan ( $g a p$ ) atau perbedaan antara harapan pengunjung dan kenyataan yang mereka terima. Harapan pengunjung sama dengan keinginan pengunjung yang ditentukan oleh informasi yang mereka terima dari mulut ke mulut, kebutuhan pribadi, pengalaman masa lalu dan komunikasi eksternal melalui iklan dan promosi. Jika kesenjangan antara harapan dan kenyataan cukup besar, hal ini menunjukkan bahwa perusahaan tidak mengetahui apa yang diinginkan oleh pengunjungnya.

Kepuasan konsumen merupakan prioritas paling utama dalam perusahaan, maka perusahaan harus memiliki fokus pada pelanggan. Menurut Tjiptono, F, (2001), tingkat kepuasan pelanggan ditentukan oleh lima faktor utama dan harus diperhatikan oleh perusahaan, yaitu :

- Kualitas produk, konsumen akan merasa puas bila evaluasi mereka menunjukkan bahwa produk yang mereka gunakan memang berkualitas.

- Kualitas pelanggan, konsumen akan merasa puas bila mereka mendapatkan pelayanan yang baik atau yang sesuai dengan yang diharapkan. 
- Emosional, konsumen akan merasa bangga dan mendapatkan keyakinan bahwa orang lain akan kagum terhadap mereka (konsumen), bila menggunakan produk tertentu yang cenderung mempunyai tingkat kepuasan yang lebih tinggi.

- Harga, produk yang mempunyai kualitas yang sama tapi menetapkan harga yang relatif murah akan memberikan nilai yang lebih tinggi kepada konsumennya.

- Biaya, konsumen yang tidak perlu mengeluarkan biaya tambahan atau yang tidak perlu membuang waktu untuk mendapatkan suatu produk cenderung puas akan produk tersebut.

\section{Kerangka Pemikiran}

Kerangka pemikiran dalam penelitian ini menggambarkan bagaimana pengaruh kualitas pelayanan dan hubungan dari variabel independen dalam hal ini kualitas jasa yang meliputi Reliability $\left(\mathrm{X}_{1}\right)$, Responsiveness $\left(\mathrm{X}_{2}\right)$, Assurance $\left(\mathrm{X}_{3}\right)$, Empathy $\left(\mathrm{X}_{4}\right)$ dan Tangibles $\left(\mathrm{X}_{5}\right)$ terhadap variabel dependen yaitu kepuasan pengunjung $(\mathrm{Y})$, digambarkan sebagai berikut:

\section{Gambar 1. Keranga Pemikiran}

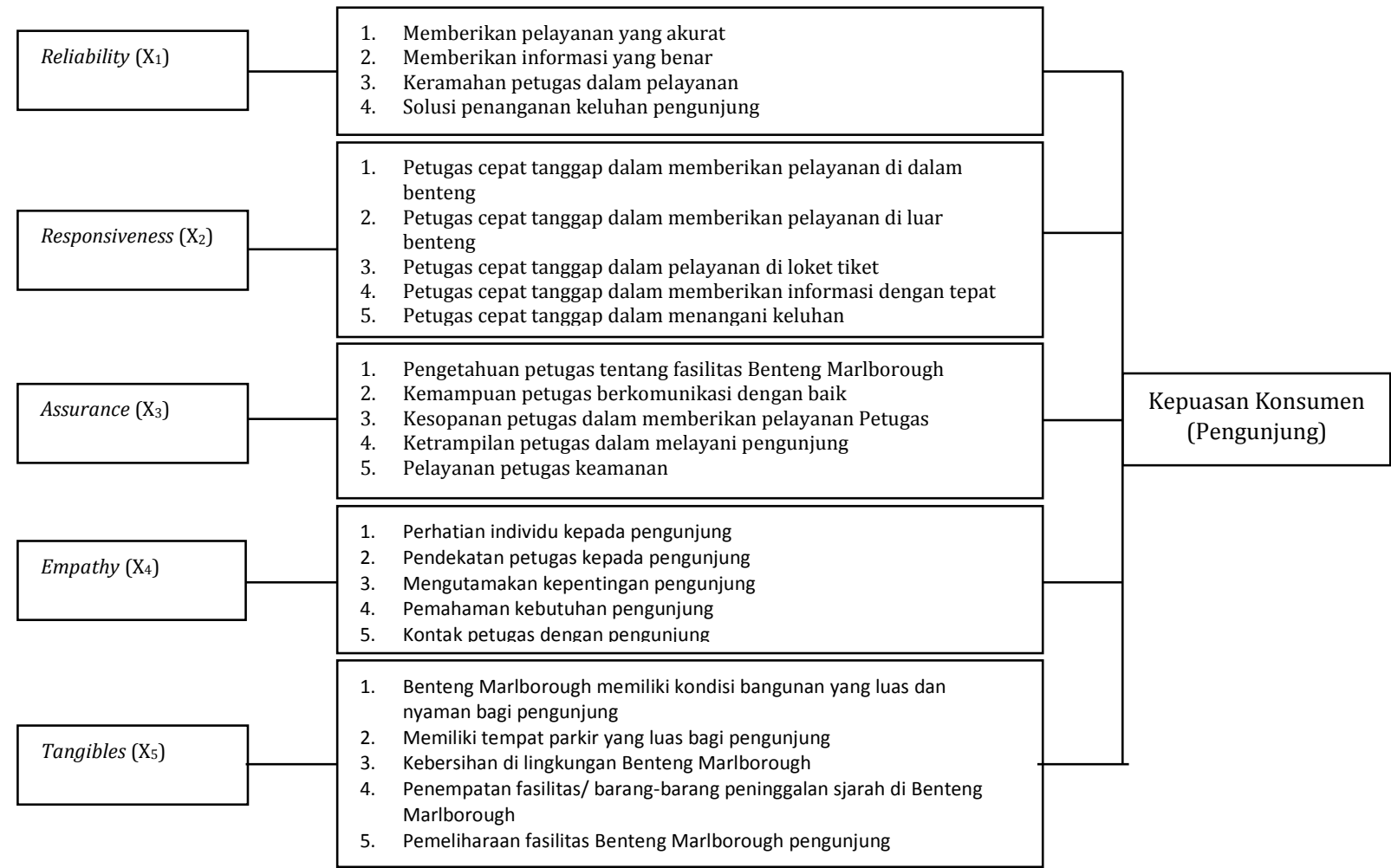

Sumber : Zeithaml, Berry dan Parasuraman, (dalam Zulian Yamit, 2005)

\section{Hipotesis Penelitian}

Berdasarkan kerangka pemikiran di atas, dibuat hipotesis penelitian sebagai berikut:

1. Secara simultan (serentak) ada pengaruh positif yang signifikan antara dimensi kualitas pelayanan SERVQUAL (Reliability, Responsiveness, Assurance, Empathy dan Tangibles) terhadap kepuasan pengunjung di objek wisata sejarah Benteng Marlborough.

2. Secara parsial (secara individu) ada pengaruh positif dan signifikan antara dimensi kualitas pelayanan SERVQUAL (Reliability, Responsiveness, Assurance, Empathy dan Tangibles) terhadap kepuasan pengunjung di objek wisata sejarah Benteng Marlborough, 


\section{METODA PENELITIAN}

\section{Desain Penelitian}

Desain penelitian menurut Mc Millan dalam Ibnu Hadjar (1999:102) dalam Rakim's Blog Desain Penelitian adalah rencana dan struktur penyelidikan yang digunakan untuk memperoleh bukti-bukti empiris dalam menjawab pertanyaan penelitian. Dalam penelitian eksperimental, desain penelitian disebut desain eksperimental. Desain eksperimen dirancang sedemikian rupa guna meningkatkan validitas internal maupun eksternal.

Secara garis besar ada dua macam tipe desain, yaitu: Desain Ex Post Facto dan Desain Eskperimental. Faktor-faktor yang membedakan kedua desain ini ialah pada desain pertama tidak terjadi manipulasi varaibel bebas sedang pada desain yang kedua terdapat adanya manipulasi variabel bebas. Berdasarkan kedua tipe disain tersebut peneliti menggunakan bentuk design yang pertama yaitu Desain Ex Post Facto. Adapun sub Desain Ex post Facto adalah :

a. Studi Lapangan:

Studi lapangan merupakan desain penelitian yang mengkombinasikan antara pencarian literature (Literature Study), survei berdasarkan pengalaman dan/atau studi kasus dimana peneliti berusaha mengidentifikasi variabel-variabel penting dan hubungan antar variabel tersebut dalam suatu situasi permasalahan tertentu. Studi lapangan umumnya digunakan sebagai sarana penelitian lebih lanjut dan mendalam.

b. Survei

Desain survei tergantung pada penggunaan jenis kuesioner. Survei memerlukan populasi yang besar jika peneliti menginginkan hasilnya mencerminkan kondisi nyata. Semakin sampelnya besar, survei semakin memberikan hasil yang lebih akurat. Dengan survei seorang peneliti dapat mengukap masalah yang banyak, meski hanya sebatas dipermukaan. Sekalipun demikian, survei bermanfaat jika peneliti menginginkan informasi yang banyak dan beraneka ragam. Metode survei sangat popular karena banyak digunakan dalam penelitian bisnis. Keunggulan survei yang lain ialah mudah melaksanakan dan dapat dilakukan secara cepat.

Sebelum memulai dengan desain spesifik Ex Post facto maka perlu dibuat sistem notasi yang digunakan terlebih dahulu. Sistem notasi tersebut adalah sebagai berikut:

$\mathrm{X}$ : Digunakan untuk mewakili pemaparan (exposure) suatu kelompok yang diuji terhadap suatu perlakuan eksperimental pada variabel bebas yang kemudian efek pada variabel tergantungnya akan diukur.

Y : Menunjukkan adanya suatu pengukuran atau observasi terhadap variabel tergantung (terikat) yang sedang diteliti pada individu, kelompok atau obyek tertentu.

$\mathrm{R}$ : Menunjukkan bahwa individu atau kelompok telah dipilih dan ditentukan secara random untuk tujuan-tujuan studi, atau jumlah responden yang dijadikan sampel penelitian.

\section{Teknik Analisis Data}

Teknik analisis data yang digunakan dalam penelitian ini adalah:

\section{a. Analisis Deskriptif}

Analisis deskriptif adalah analisis yang didasarkan pada data yang diperoleh dari para responden dan dinyatakan dalam bentuk tabulasi data dengan menggunakan tabel distribusi frekuensi. Dalam penelitian ini analisis berdasarkan uraian hasil jawaban dari kuesioner yang telah disebarkan kepada pengunjung yang telah menggunakan pelayanan jasa pada objek wisata Benteng Marlborough Bengkulu.

\section{b. Analisis Statistik}

Analisis Statistik adalah analisis dengan menggunakan pendekatan atau rumus statistik. Dalam penelitian ini analisis statistik digunakan untuk menguji apakah terdapat pengaruh yang signifikan atau tidak dari variabel Reliability, Responsiveness, Assurance, Emphaty dan Tangible terhadap kepuasan pengunjung pada objek wisata Benteng Marlborough. 
Analisis statistik yang digunakan meliputi analisis regresi dan korelasi berganda, analisis uji simultan (uji- F), analisis uji parsial (uji- t), dan analisis koefisien determinasi.

Analisis uji hipotesis dilakukan dengan uji statistik yaitu uji-F dan uji-t, sebelumnya dilakukan pengujian terhadap pelanggaran asumsi klasik supaya model regresi yang dihasilkan dengan metode kuadrat terkecil (Ordinary Least Square), sehingga menghasilkan model regresi estimator yang tidak bias dan terbaik (BLUE).

\section{HASIL PENELITIAN DAN PEMBAHASAN}

\section{Deskripsi Profil Responden}

Berdasarkan hasil penelitian yang dilakukan terhadap 100 orang responden berdasarkan rumus Slovin, maka peneliti akan menyajikan gambaran tentang deskripsi responden yang digunakan sebagai sampel dalam penelitian ini.

\section{Distribusi Responden Berdasarkan Jenis Kelamin}

Berdasarkan hasil penelitian yang dilakukan dengan penyebaran kuesioner kepada 100 orang responden, maka dapat diketahui distribusi responden berdasarkan jenis kelamin sebagaimana yang tertera dalam tabel berikut ini:

\section{Tabel 1. Distribusi Responden Berdasarkan Jenis Kelamin}

\begin{tabular}{|c|c|c|c|}
\hline No & Jenis kelamin & Jumlah (orang) & Persentase (\%) \\
\hline 1. & Laki-laki & 53 & 53 \\
2. & Perempuan & 47 & 47 \\
\hline & Jumlah & 100 & 100 \\
\hline
\end{tabular}

Sumber : Pengolahan Data Primer, 2013

Berdasarkan tabel 4.1 sebagaimana tertera di atas, dapat diketahui bahwa responden yang dijadikan sampel penelitian ini didominasi oleh laki-laki yaitu sebanyak 53 orang (53\%) dari 100 orang responden selanjutnya diikuti oleh wanita yaitu 47 orang atau $47 \%$. Jumlah pengunjung yang hamper berimbang antara jenis kelamin laki-laki dan perempuan ini diduga berkaiatan dengan objek wisata Benteng Marlborough yang dapat diterima oleh laki-laki maupun kaum perempuan.

\section{Distribusi Responden Berdasarkan Usia}

Berdasarkan hasil penelitian yang dilakukan dengan penyebaran kuesioner kepada 100 orang responden, maka dapat diketahui distribusi responden berdasarkan jenis kelamin sebagaimana yang tertera dalam tabel berikut ini:

Tabel 2. Distribusi Responden Berdasarkan Usia

\begin{tabular}{|c|c|c|c|}
\hline No & Tingkat Usia (Tahun) & Jumlah (Orang) & Persentase (\%) \\
\hline 1. & $10-20$ & 30 & 27 \\
2. & $21-30$ & 27 & 23 \\
3. & $31-40$ & 23 & 20 \\
4. & $\geq 41$ & 20 & 100 \\
\hline
\end{tabular}

Sumber : Pengolahan Data Primer, 2013

Berdasarkan tabel sebagaimana tertera di atas, dapat diketahui bahwa responden yang dijadikan sampel penelitian ini didominasi oleh tingkat usia 10- 20 tahun, yaitu sebanyak 30 orang (30\%) dari 100 orang responden. Selanjutnya diikuti oleh responden pada tingkat usia 21 - 30 tahun yaitu 27 orang atau $27 \%$. Kemudian untuk tingkat usia 31 40 tahun berjumlah 23 orang atau $23 \%$, sedangkan untuk usia lebih atau sama dengan usia 41 tahun berjumlah 20 orang atau $20 \%$ dari total responden yang dijadikan sampel dalam panelitian ini. Kuesioner ini menjelaskan bahwa konsumen/pengunjung objek wisata Benteng Marlborough kebanyakan masih berusia produktif, yaitu kebanyakan statusnya masih pelajar atau mahasiswa. 


\section{Distribusi Responden Berdasarkan Tingkat Pekerjaan}

Dalam penelitian ini tingkat pendidikan responden dibagi menjadi lima (5) tingkatan, yaitu: pelajar/mahasiswa, Pegawai Negeri Sipil, Pegawai Swasta, Wiraswasta, dan lainnya. Berdasarkan hasil penelitian dengan penyebaran kuesioner kepada responden maka dapat diketahui distribusi responden berdasarkan tingkat usia sebagaimana terlihat pada tabel berikut ini :

\section{Tabel 3. Distribusi Responden Berdasarkan Pekerjaan}

\begin{tabular}{|c|c|c|c|}
\hline No & Tingkat Paendidikan & Jumlah (orang) & Persentase (\%) \\
\hline 1. & Pelajar/mahasiswa & 33 & 17 \\
2. & Pegawai Negeri Sipil & 17 & 20 \\
3. & Pegawai Swasta & 20 & 15 \\
4. & Wiraswasta & 15 & 15 \\
\hline 5. & Lainnya & 15 & 100 \\
\hline
\end{tabular}

Sumber : Pengolahan Data Primer, 2013

Berdasar tabel di atas dimana jumlah responden yang mendominasi yang menjadi sampel dalam penelitian ini adalah pelajar/mahasiswa yang berjumlah 33 orang atau $33 \%$ dari 100 orang responden. Kemudian untuk jenis pekerjaan Pegawai Negeri Sipil adalah 17 orang atau $17 \%$ kemudian jenis pekerjaan swasta sebanyak 20 orang atau $20 \%$. Sedangkan jumlah terkecil sampel terambil dari jenis pekerjaan wiraswasta dan lainnya masing-masing 15 orang atau $15 \%$ dari total responden.

Kuesioner ini mampu menjelaskan bahwa pengunjung objek wisata Benteng Marlborough banyak dikunjungi oleh para pelajar dan mahasiswa dimana maksud dan tujuan mereka adalah berwisata sambil belajar tentang sejarah peninggalan kolonial Ingris pada waktu penjajahan dahulu kala.

\section{Distribusi Responden Berdasarkan Tujuan Kunjungan}

Terdapat empat klasifikasi yang digunakan untuk mengelompokkan tujuan kunjungan pengunjung yaitu dengan tujuan belajar, hiburan, rekreasi, dan lainnya. Berdasarkan hasil penelitian yang dilakukan dengan penyebaran kuesioner kepada 100 orang responden, maka dapat diketahui distribusi responden berdasarkan tujuan kunjungan dapat dilihat pada tabel berikut ini:

Tabel 4. Distribusi Responden Berdasarkan Tujuan Kunjungan

\begin{tabular}{|c|c|c|c|}
\hline No & Tujuan Kunjungan & Jumlah (Orang) & Persentase (\%) \\
\hline 1. & Belajar & 31 & 31 \\
2. & Hiburan & 25 & 25 \\
3. & Rekreasi & 27 & 27 \\
4. & Lainnya & 17 & 17 \\
\hline & Jumlah & 100 & 100 \\
\hline
\end{tabular}

Sumber : Pengolahan Data Primer, 2013

Berdasarkan tabel sebagaimana tertera di atas, dapat diketahui bahwa responden yang dijadikan sampel penelitian ini didominasi tujuan untuk belajar yaitu sebanyak 31 orang (31\%). Selanjutnya diikuti oleh responden dengan tujuan hiburan yaitu 25 orang atau $27 \%$. Kemudian responden dengan tujuan rekreasi berjumlah 27 orang atau $27 \%$ dan dengan tujuan lainnya sebanyak 17 orang atau 17 persen. Hasil ini menunjukkan bahwa tujuan konsumen/pengunjung untuk mengunjungi objek wisata Benteng Marlborough kebanyakan bertujuan untuk belajar sambil berekreasi karena benteng Marborough adalah salah satu situs peninggalan sejarah penjajahan Inggris di Kota Bengkulu.

\section{Rekapitulasi Hasil Tanggapan Kualitas Pelayanan Objek Wisata Benteng Marlborough}

Berdasarkan penjelasan dari tanggapan masing-masing responden dapat diambil kesimpulan pada tabel berikut ini. 
Tabel 5. Rekapitulasi Hasil Tanggapan Kualitas Pelayanan Objek Wisata di Benteng Marlborough Kota Bengkulu

\begin{tabular}{|c|l|c|c|}
\hline No & \multicolumn{1}{|c|}{ Variabel } & Nilai Rata-rata & Indikator \\
\hline 1 & Reliability & 3,76 & Baik \\
\hline 2 & Responsiveness & 3,59 & Baik \\
\hline 3 & Assurance & 3,78 & Baik \\
\hline 4 & Emphaty & 3,57 & Baik \\
\hline 5 & Tangble & 3,53 & Baik \\
\hline
\end{tabular}

Sumber : Pengolahan Data Primer, 2013

Dengan demikian dapat ditarik kesimpulan berdasarkan nilai rata-rata pada setiap variabel dan indikatornya adalah sebagai berikut:

a. Reliability (keandalan), yaitu kemampuan dalam memberikan pelayanan dengan segera dan memuaskan pengunjung serta sesuai dengan yang dijanjikan mendapat penilaian yang baik dari pengunjung.

b. Ressponsiveness (daya tanggap), yaitu keinginan staf untuk membantu para pengunjung dan memberikan pelayanan dengan tanggap mendapat penilaian yang baik dari pengunjung.

c. Assurance (Jaminan), yaitu mencakup kemampuan, kesopanan, dan sifat dapat dipercaya yang dimiliki staf, bebas dari bahaya, resiko maupun keragu-raguan mendapat penilaian yang baik dari pengunjung.

d. Emphaty meliputi kemudahan dalam melakukan hubungan, komunikasi yang baik, dan perhatian dengan tulus terhadap kebutuhan pengunjung, mendapat penilaian yang baik dari pengunjung.

e. Tangibles (bukti langsung) yaitu meliputi fasilitas fisik, perlengkapan, karyawan, dan sarana komunikasi mendapatkan penilaian yang baik dari pengunjung.

\section{Tanggapan Responden Terhadap Kepuasan Pengunjung}

Dengan interval (0.80) maka dapat ditetapkan kriteria penilaian atau skala persepsi untuk menentukan kualitas penilaian kepuasan konsumen sebagai variabel terikat (Y) terhadap variabel penelitian. Adapun kriteria penilaian yang dimaksud adalah :

Tabel 6. Tanggapan Responden Terhadap Kepuasan Konsumen Objek Wisata di Benteng Marlborough Kota Bengkulu

\begin{tabular}{|c|c|c|c|c|c|c|c|c|}
\hline \multirow{2}{*}{ No } & \multirow{2}{*}{ Indikator } & \multicolumn{5}{|c|}{ Respon Konsumen } & \multirow{2}{*}{ Total } & \multirow{2}{*}{$\begin{array}{l}\text { Rata- } \\
\text { rata }\end{array}$} \\
\hline & & $(5)$ & (4) & $(3)$ & $(2)$ & (1) & & \\
\hline 1 & Objek wisata sejarah yang berkualitas & 24 & 32 & 28 & 16 & 0 & 364 & 3,64 \\
\hline 2 & $\begin{array}{l}\text { Kualitas dan pengetahuan tentang sejarah } \\
\text { para pengunjung }\end{array}$ & 15 & 30 & 41 & 14 & 0 & 346 & 3,46 \\
\hline 3 & $\begin{array}{l}\text { Tingkat emosional pengunjung tentang } \\
\text { sejarah nasional }\end{array}$ & 20 & 27 & 36 & 17 & 0 & 350 & 3,50 \\
\hline 4 & Harga tiket masuk yang terjangkau & 41 & 27 & 22 & 10 & 0 & 399 & 3,99 \\
\hline 5 & Penghematan biaya yang dikeluarkan & 24 & 33 & 32 & 11 & 0 & 370 & 3,70 \\
\hline & Rata-rata & & & & & & & 3,66 \\
\hline
\end{tabular}

Sumber : Pengolahan Data Primer, 2013.

Berdasarkan tabel di atas dapat diketahui bahwa nilai rata-rata tertinggi yang diberikan oleh responden mengenai kepuasan konsumen adalah sebesar 3,65 (Memuaskan), dengan demikian nilai tersebut berada di rank 3,40 - 4,19. Berdasarkan kriteria penilaian yang sudah ditentukan, angka tersebut masuk kedalam kriteria penilaian memuaskan, dengan demikian dapat disimpulkan bahwa para pengunjung merasa puas dengan layanan yang diberikan oleh karyawan setelah para pengunjung mengunjungi Benteng Marlborough di Kota Bengkulu. 


\section{Pengaruh Kualitas Pelayanan Jasa Terhadap Kepuasan Konsumen Pada Objek Wisata Benteng Marlborough Pekanbaru.}

Pada penelitian ini analisis regresi hubungan antara kualitas pelayanan terhadap kepuasan konsumen yang digunakan adalah analisis regresi linier berganda. Analisis ini digunakan untuk mengetahui pengaruh Reliability, Responsiveness, Assurance, Emphaty dan Tangible terhadap kepuasan konsumen. Adapun rekapitulasi out put hasil penelitian dengan komputer SPSS for Windows Release 16,00, adalah:

Tabel 7. Koefesien Regresi Pelayanan Terhadap Kepuasan Konsumen objek Wisata Benteng Marlborough Kota Bengkulu

\begin{tabular}{|c|c|c|c|c|c|}
\hline No & Variabel & $\begin{array}{l}\text { Koefisien } \\
\text { Regresi }\end{array}$ & Thitung & Sig. & $\begin{array}{l}T_{\text {tabel }} \mathrm{df}=(\mathrm{n}-\mathrm{k}) \\
=100-6=94\end{array}$ \\
\hline 1 & Konstanta & $-1,220$ & $-4,435$ & 0,000 & 1,661 \\
\hline 2 & $\mathrm{X}_{1} \cdot$ Reliability & 0,078 & 1,718 & 0,089 & 1,661 \\
\hline 3 & $\mathrm{X}_{2 .}$ Responsiveness & 0,173 & 3,784 & 0,000 & 1,661 \\
\hline 4 & $\mathrm{X}_{3}$. Assurance & 0,298 & 5,849 & 0,000 & 1,661 \\
\hline 5 & $\mathrm{X}_{4 . E m p h a t y}$ & 0,415 & 8,221 & 0,000 & 1,661 \\
\hline 6 & $\mathrm{X}_{5 . T a n g i b l e}$ & 0,101 & 1,819 & 0,072 & 1,661 \\
\hline \multicolumn{2}{|c|}{$\begin{array}{l}\text { Korelasi Ganda (R) } \\
\text { Koef. Determinasi }\left(\mathrm{R}^{2}\right)\end{array}$} & \multicolumn{3}{|l|}{$\begin{array}{l}0,988^{\mathrm{a}} \\
0,976\end{array}$} & \\
\hline \multicolumn{2}{|c|}{$\begin{array}{l}\text { Adjusted } \mathrm{R}^{2} \\
\text { F }_{\text {hitung }}\end{array}$} & \multicolumn{3}{|l|}{$\begin{array}{l}0,974 \\
755,677 \\
\end{array}$} & \\
\hline
\end{tabular}

Sumber : Pengolahan Data Primer, 2013. (Dari lampiran VI)

Berdasarkan tabel di atas, dapat dirumuskan persamaan regresi linier berganda sebagai berikut:

$Y=-1,220+0,078 X_{1}+0,173 X_{2}+0,298 X_{3}+0,415 X_{4}+0,101 X_{5}+e_{i}$

\section{Uji Statistik}

Uji F dan uji t digunakan untuk membuktikan pengaruh Reliability, Responsiveness, Assurance, Emphaty dan Tangible terhadap kepuasan konsumen objek wisata Benteng Marborough secara simultan (uji F) dan secara parsial (uji t) dengan asumsi bahwa variabel yang lain tetap atau konstan. Kemudian dilanjutkan dengan pengujian koefisien korelasi berganda dan koefisien korelasi parsial. Berdasarkan hasil perhitungan dengan menggunakan program statistik komputer SPSS for Windows Release 16,00 diperoleh hasil sebagai berikut:

\section{Pengujian Secara Serempak (Uji F)}

Uji $\mathrm{F}$ adalah uji simultan yang digunakan untuk mengetahui pengaruh variabel independen $\left(\mathrm{X}_{1}, \mathrm{X}_{2}, \mathrm{X}_{3}, \mathrm{X}_{4}, \mathrm{X}_{5}\right)$ secara simultan terhadap variabel dependen ( $\mathrm{Y}$ ).

1) Perumusan hipotesis

Ho : $b_{1} \neq b_{2} \neq b_{3} \neq b_{4} \neq b_{5} \neq 0$ (secara simultan tidak ada pengaruh yang signifikan antara variabel Reliability, Responsiveness, Assurance, Emphaty dan Tangible terhadap kepuasan konsumen objek wisata Benteng Marlborough Kota Bengkulu).

$\mathrm{Ha}: \mathrm{b}_{1}=\mathrm{b}_{2}=\mathrm{b}_{3}=\mathrm{b}_{4}=\mathrm{b}_{5}=0$ (secara simultan ada pengaruh yang signifikan antara variabel Reliability, Responsiveness, Assurance, Emphaty dan Tangible terhadap kepuasan pengunjung objek wisata Benteng Marlborough Kota Bengkulu).

2) Kriteria pengujian

3) Apabila $\mathrm{F}_{\text {-hitung }}<\mathrm{F}_{\text {-tabel, }}$, maka Ho diterima dan Ha ditolak, artinya secara simultan variabel Reliability, Responsiveness, Assurance, Emphaty dan Tangible tidak berpengaruh signifikan terhadap kepuasan konsumen objek wisata Benteng Marlborough Kota Bengkulu. Bila F. hitung $\geq \mathrm{F}_{\text {-tabel, }}$ maka Ho ditolak dan Ha diterima, artinya secara simultan variabel Reliability, Responsiveness, Assurance, Emphaty dan Tangible ada berpengaruh signifikan terhadap kepuasan pengunjung objek wisata Benteng Marlborough Kota Bengkulu. 
4) Dengan level of significant $\alpha=5 \%$ dan df pembilang $k-1=5-1=4$ dan penyebut $n-k=100$ $4=96$, diperoleh F-tabel $=2,450$.

5) Statistik uji $\mathrm{F}=755,677$.

6) Hasil uji:

Diperoleh nilai $\mathrm{F}_{\text {-hitung }}=755,677>\mathrm{F}_{\text {-tabel }}=2,450$, maka Ho ditolak atau Ha diterima, artinya ada pengaruh secara simultan dan sangat signifikan antara Reliability $\left(\mathrm{X}_{1}\right)$, Responsiveness $\left(\mathrm{X}_{2}\right)$, Assurance $\left(\mathrm{X}_{3}\right)$, Emphaty $\left(\mathrm{X}_{4}\right)$, dan Tangible $\left(\mathrm{X}_{5}\right)$ terhadap kepuasan pengunjung objek wisata di Benteng Marlborough Kota Bengkulu (Y).

\section{Pengujian Hipotesis Secara Parsial (Uji t)}

1) Pengujian pengaruh variabel Reliability $\left(X_{1}\right)$ terhadap variabel kepuasan pengunjung objek wisata Benteng Marlborough (Y).

a. Dengan taraf nyata $(\alpha)=5 \%=0,05$ dan dengan derajat kebebasan (degree of freedom) yaitu : $\mathrm{df}=(\mathrm{n}-\mathrm{k})=100-6=94$, diperoleh $\mathrm{t}_{\text {-tabel }}=1,661$ dan dari hasil regresi berganda diperoleh t-hitung = 1,718 atau Sig. 0,089.

b. Berdasarkan hasil olah data diperoleh nilai $t_{\text {-hitung }}=1,718>t_{\text {tabel }}=1,661$ tetapi $\alpha=0,05<$ Sig.= 0,089, maka disimpulkan bahwa ada pengaruh positif tetapi tidak signifikan antara Reliability $\left(\mathrm{X}_{1}\right)$ terhadap kepuasan konsumen objek wisata Benteng Marlborough ( $\mathrm{Y}$ ).

2) Pengujian pengaruh variabel Responsiveness $\left(\mathrm{X}_{2}\right)$ terhadap variabel kepuasan konsumen objek wisata Benteng Marlborough (Y).

a. Dengan taraf nyata $(\alpha)=5 \%=0,05$ dan dengan derajat kebebasan (degree of freedom) yaitu $: \mathrm{df}=(\mathrm{n}-\mathrm{k})=100-6=94$, diperoleh $\mathrm{t}_{\text {tabel }}=1,661$ dan dari hasil regresi berganda diperoleh $t_{\text {hitung }}=3,784$.

b. Berdasarkan hasil olah data diperoleh nilai $t_{\text {-hitung }}=3,784>t_{\text {tabel }}=1,661$ atau $\alpha=0,05>$ Sig. $=0,000$, maka disimpulkan bahwa ada pengaruh secara positif dan signifikan antara Responsiveness $\left(\mathrm{X}_{2}\right)$ terhadap kepuasan konsumen objek wisata Benteng Marlborough (Y).

3) Pengujian pengaruh variabel Assurance $\left(\mathrm{X}_{3}\right)$ terhadap variabel kepuasan konsumen objek wisata Benteng Marlborough (Y).

a. Dengan taraf nyata $(\alpha)=5 \%=0,05$ dan dengan derajat kebebasan (degree of freedom) yaitu : $\mathrm{df}=(\mathrm{n}-\mathrm{k})=100-6=94$, diperoleh $\mathrm{t}_{\text {tabel }}=1,661$ dan dari hasil regresi berganda diperoleh $\mathrm{t}_{\text {hitung }}=5,849$.

b. Berdasarkan hasil olah data diperoleh nilai $t_{\text {-hitung }}=5,849>t_{\text {tabel }} 1,661$ atau $\alpha=0,05>$ Sig. $=$ 0,000, maka disimpulkan bahwa ada pengaruh secara positif dan signifikan antara Assurance $\left(\mathrm{X}_{3}\right)$ terhadap kepuasan konsumen objek wisata Benteng Marlborough (Y).

4) Pengujian pengaruh variabel Emphaty $\left(\mathrm{X}_{4}\right)$ terhadap variabel kepuasan konsumen objek wisata Benteng Marlborough (Y)

a. Dengan taraf nyata $(\alpha)=5 \%=0,05$ dan dengan derajat kebebasan (degree of freedom) yaitu $: \mathrm{df}=(\mathrm{n}-\mathrm{k})=100-6=94$, diperoleh $\mathrm{t}_{\text {-tabel }}=1,661$ dan dari hasil regresi berganda diperoleh $t_{\text {hitung }}=8,221$.

b. Berdasarkan hasil olah data diperoleh nilai $t_{\text {-hitung }} 8,221>t_{\text {tabel }} 1,661$ atau $\alpha=0,05>$ Sig. $=$ 0,000, maka disimpulkan bahwa ada pengaruh secara positif dan signifikan antara Emphaty $\left(\mathrm{X}_{4}\right)$ terhadap kepuasan konsumen objek wisata Benteng Marlborough (Y).

5) Pengujian pengaruh variabel Tangible $\left(\mathrm{X}_{5}\right)$ terhadap variabel kepuasan konsumen objek wisata Benteng Marlborough (Y).

a. Dengan taraf nyata $(\alpha)=5 \%=0,05$ dan dengan derajat kebebasan (degree of freedom) yaitu : $\mathrm{df}=(\mathrm{n}-\mathrm{k})=100-6=94$, diperoleh $\mathrm{t}_{\text {tabel }}=1,661$ dan dari hasil regresi berganda diperoleh $t_{\text {hitung }}=1,819$.

b. Berdasarkan hasil olah data diperoleh nilai $t_{\text {-hitung }}=1,819>t_{\text {tabel }} 1,661$ atau $\alpha=0,05<$ Sig. $=$ 0,072, maka disimpulkan bahwa ada pengaruh positif tetapi tidak signifikan antara Tangible $\left(\mathrm{X}_{5}\right)$ terhadap kepuasan konsumen objek wisata Benteng Marlborough (Y). 


\section{Pengujian $\mathbf{R}^{2}$ (Koefisien Determinasi)}

Koefisien Determinasi $\left(\mathrm{R}^{2}\right)$ ini digunakan untuk mengetahui seberapa besar kemampuan variabel independen dalam menjelaskan secara komprehensif terhadap variabel dependen. Nilai $\mathrm{R}^{2}$ (Koefisien Determinasi) mempunyai range antara 0-1. Semakin besar $\mathrm{R}$ mengindikasikan semakin besar kemampuan variabel independen dalam menjelaskan variabel dependen.

Hasil dari regresi dengan metode OLS diperoleh $\mathrm{R}^{2}$ (Koefisien Determinasi) sebesar 0,976, artinya variabel dependen (Y) dalam model kepuasan pengunjung objek wisata Benteng Marlborough $(\mathrm{Y})$ dijelaskan oleh variabel independen $(\mathrm{X})$ yaitu Reliability $\left(\mathrm{X}_{1}\right)$, Responsiveness $\left(\mathrm{X}_{2}\right)$, Assurance $\left(\mathrm{X}_{3}\right)$, Emphaty $\left(\mathrm{X}_{4}\right)$, dan Tangible $\left(\mathrm{X}_{5}\right)$ sebesar $97,6 \%$, sedangkan sisanya sebesar $2,4 \%$ dijelaskan oleh faktor lain yang tidak dihipotesiskan atau variabel lain yang tidak dimasukkan di dalam model persamaan ini.

\section{KESIMPULAN}

Berdasarkan hasil penelitian yang sudah di analisis, maka peneliti mendapatkan kesimpulan-kesimpulan sebagai berikut:

1. Bahwa kualitas pelayanan di Benteng Mrlborough Bengkulu yang terdiri dari Reliability (keandalan), Ressponsiveness, Assurance (Jaminan), Emphaty, Tangibles (bukti langsung) mendapatkan penilaian yang baik dari rata-rata pengunjung.

2. Berdasarkan penelitian yang telah dilakukan dapat diketahui bahwa nilai rata-rata tertinggi yang diberikan oleh responden mengenai kepuasan konsumen adalah sebesar 3,65 (Memuaskan), dengan demikian nilai tersebut berada di rank 3,40 - 4,19. Berdasarkan kriteria penilaian yang sudah ditentukan, angka tersebut masuk kedalam kriteria penilaian memuaskan, dengan demikian para pengunjung merasa puas dengan layanan yang diberikan oleh karyawan setelah para pengunjung mengunjungi Benteng Marlborough di Kota Bengkulu.

3. Kualitas pelayanan mempunyai pengaruh positif terhadap kepuasan pengunjung pada objek wisata Benteng Marlborough Kota Bengkulu. Hal ini ditunjukkan dengan uji F dan uji t nilai tstatistiknya lebih besar dari t-tabel, yaitu meliputi nilai variabel Reliability ( $\left.\mathrm{X}_{1}\right)$, Responsiveness $\left(\mathrm{X}_{2}\right)$, Assurance $\left(\mathrm{X}_{3}\right)$, Emphaty $\left(\mathrm{X}_{4}\right)$, dan Tangible $\left(\mathrm{X}_{5}\right)$ terhadap kepuasan pengunjung ( $\mathrm{Y}$ ) objek wisata Benteng Marlborough Kota Bengkulu, tetapi untuk variabel Reliability $\left(\mathrm{X}_{1}\right)$ dan variabel Tangible $\left(\mathrm{X}_{5}\right)$ pengaruhnya tidak cukup signifikan.

\section{DAFTAR PUSTAKA}

Engel, James F, Blackwell, Roger D, and Miniard, Paul W. 1994. Perilaku Konsumen. Terjemahan Budiyanto. Jakarta, Binarupa Aksara.

Gaspersz, Vincent. 2002. Manajemen Kualitas dalam Industri Jasa Jakarta, Gramedia.

Ghozali, Imam. 2001. Aplikasi Analisis Multivariat Dengan Program SPSS. Badan Penerbit UNDIP

Hartono. 2005. SPSS. Analisis Data dan Penelitian dengan Komputer. Edisi pertama. Yogyakarta, Penerbit Aditya Media bekerjasama dengan LSFK3P.

Kuncoro, Mudrajad. 2001. Metode Kuantitatif, Teori dan Aplikasi Untuk Bisnis dan Ekonomi, Yogyakarta, UPP AMP YKPN.

Mulyono, Sri. 2006. Statistika Untuk Ekonomi \& Bisnis. Edisi Ketiga, Jakarta, Lembaga Penerbit Fakultas Ekonomi Universitas Indonesia.

Parasuraman, et.al, 1985, Pelayanan Pelanggan yang Sempurna, Yogyakarta, Kunci Ilmu. Bandung 
Philip, Kotler. 1980. Marketing Management. Analysis, Planning, and Control. Edisi ke empat. London, Prentice-Hall, inc.

Priyatno, Dwi. 2008. Mandiri Belajar SPSS (Statistical Product and Service Solution), Untuk Analisis Data \& Uji Statistik. Edisi Pertama. Yogyakarta, Penerbit Mediakom.

Purnama, Nursya'bani. 2006. Manajemen Kualitas Prospektif Global. Edisi Pertama, Cetakan Pertama. Yogyakarta, Penerbit Ekonisia Kampus Fakultas Ekonomi UII.

Radiosunu. 2001. Manajemen Pemasaran : Suatu Pendekatan Analisis. Yogyakarta, BPFE.

Sinamora, B, 2004. Riset Pemasaran: Falsafah, Teori, dan Aplikasi. Jakarta, Gramedia Pustaka Utama.

Singaribun, Masri editor Effendi, Sofian, 1987. Metode Penelitian Survai. Yogyakarta, PT. Midas Surya Grafindo.

Sugiyono. (2007). Metode Penelitian Bisnis, Bandung, Alfabeta.

Swastha, Basu DH dan T Hani Handoko, 2001. Manajemen Pemasaran, Analisa Perilaku Konsumen. Yogyakarta, BPFE.

Tjiptono, Fandy. 2004. Manajemen Jasa. Yogyakarta. Penerbit Andi.

1996. Kiat Menangani Keluhan Pelanggan, Bisiness News, Ruang Strategi Usaha No. 317 (10 April), Th VII, pp. 1-4.

Umar, Husein. 2000. Riset Pemasaran dan Prilaku Konsumen. Jakarta. PT. Gramedia Pustaka. wahana Komputer Semarang. 2000. 10 Model Penelitian dan Pengolahannya dengan SPSS 10.01. Yogyakarta, Penerbit Andi.

Zeithaml, Valarie A. and Mary Jo Bitner. 1996. Service Marketing. New York, The McGraw-Hill Companies, Inc.

-, 1990. Delivering Quality Service. New York. The Free Press.

Zulian Yamit. (2005). Manajemen Kualitas Produk dan Jasa. Jakarta, Ekonisia. 